15. Poljakov Ju.A. Chelovek v povsednevnosti (istoricheskie aspekty)// Otechestvennaja istorija. - 2000. - №3.

16. Rashin A.T. Naselenie Rossii za 100 let (1811-1913 gg.): Statisticheskie ocherki. - M.: Goskomstat Rossii, 1956.

17. Rossija i SSSR v vojnah XX veka: Statisticheskoe issledovanie. - M.: Olma-Press, 2001.

18. Social'no-klassovaja struktura i demograficheskie processy v Rossii i SSSR: Voprosy kompleksnogo izuchenija: Sbornik statej. - M., 1990.

19. Trifonov I. Ja. Likvidacija jekspluatatorskih klassov v SSSR. - M.: Politizdat, 1975.

20. Urlanis B.C. Vojny i narodonaselenie Evropy: Ljudskie poteri vooruzhennyh sil evropejskih stran v vojnah XVII-XX vv. - M.: Socjekgiz, 1960.

21. Urlanis B.C. Problemy dinamiki naselenija SSSR. - M.: Nauka, 1974.

УДК 908 DOI: 10.24045/conf.2017.1.33

ПРОБЛЕМА СОЦИАЛЬНОГО НЕРАВЕНСТВА В РОССИИ И ПУТИ ЕЁ РЕШЕНИЯ В НАУЧНОЙ И ОБЩЕСТВЕННО-ПОЛИТИЧЕСКОЙ МЫСЛИ

Павлов В. С., Доктор исторических наук, профессор Института международных отношений и мировой истории Нижегородский государственньй университет им. Н.И. Лобачевского Нижний Новгород, Россия

Аннотация. Статья рассматривает острейшую проблему растущего соииального неравенства в российском обществе, пути и способы её решения в условиях экономического кризиса в стране, усугубившемся в результате политико-экономических санкиий Запада против Российской Федерачии. Она анализирует варианты выхода страны из сочиально-экономического кризиса, введения планового сегмента в развитии экономики и реализаџию социальных иенностей в рамках «православного соииализма».

Ключевые слова: сочиальная политика, сочиальное государство, социиальная справедливость, социальное неравенство, планово-рыночная экономика, «револючия сверху».

\title{
THE PROBLEM OF SOCIAL INEQUALITY IN RUSSIA AND SOLUTIONS IN SCIENTIFIC AND SOCIO-POLITICAL THOUGHT
}

\author{
Pavlov V.S., \\ Doctor of Historical Sciences, \\ Professor of \\ Institute of International Relations and World History \\ Lobachevsky State University of Nizhni Novgorod \\ Nizhni Novgorod, Russian Federation
}

\begin{abstract}
The article deals with the acute problem of growing social inequality in Russian society, ways and means of its solution in the conditions of economic crisis in the country, aggravated by the result of the political and economic
\end{abstract}


sanctions of the West against the Russian Federation. She discusses the options of exit from the economic and social crisis, the introduction of the planned segment in the economy and the realization of social values in the framework of the «Orthodox socialism».

Key words: social policy, welfare state, social justice, social inequality, planned-market economy, «revolution from above».

Рассматривая различные модели социальных государств, некоторые отечественные исследователи склонны считать, что современная Россия, её руководители ориентируются на социальное государство социалдемократического типа [9]. Оно известно более под названием «шведская модель социализма», в котором трудящиеся имеют равные возможности не только для удовлетворения своих материальных потребностей, но и запросов духовной жизни, сближение доходов и жизненных возможностей в качестве главного материального и правового условия свободы каждого. Она формировалась под влиянием достижений трудящихся в Советском Союзе, длительным пребыванием у власти (более сорока лет) шведских социалдемократов.

По нашему мнению, постсоветская российская модель социальной политики в общем и целом тяготеет к континентальной модели, поскольку её основные элементы связаны не только и даже не столько с социальной системой обеспечения, сколько с непосредственным вкладом работника и производственных структур (в том числе развитие системы накоплений за счет страховых компаний, увеличение базовой части пенсий и её индексации за счет отчислений работника в Фонд социального страхования).

В программной статье В.В. Путина «Строительство справедливости. Социальная политика для России», являющейся государственной программой на 2013-2018 годы, важнейшей задачей ставится уменьшение материального неравенства как за счёт социальной политики, так и - в первую очередь - за счёт возможностей каждому зарабатывать, обеспечивать себе достойный уровень дохода, вплоть до формирования «рабочей аристократии». Доходы высших и низших слоёв общества должны быть приведены к пропорции 12:1[10] (лидер ЛДПР В.Жириновский, считает, что она не должна превышать соотношение 10:1). Стало быть, программа В.В. Путина базируется на либеральнорыночных ценностях, где основная роль в социальной защите отводится не государству, а самому работнику. И в этой системе ценностей пока ничего не меняется. В отчётном докладе Д.Медведева Государственной думе за 2014 год, в котором социальная сфера обойдена вниманием, непреложным остаётся установка: «Утверждение о том, что мы должны всё изменить, всё скорректировать, жить по другой модели, - они неправильные. Все наши приоритеты, наши стратегические установки, должны оставаться прежними, и они останутся таковыми»[8].

Очередной экономический кризис, начавшийся в 2013 году (хотя его признаки стали очевидными в 2011 году), введение Западом экономических и политических санкций в отношении России, отстаивавшей свои внешне- 
политические интересы, крайне осложнили социальную обстановку. Неолиберальная рыночная экономика, ставшая за четверть века господствующей в стране, даже не вернулась к уровню 1990-х годов РСФСР, в то время, как весь мир ушел далеко вперед. Особенно показателен в этом отношении пример Китая., который увеличил свои экономические показатели с 1987 по 2015 год почти в 25 раз; если ВВП КНР отставал от советского в пять раз, то теперь превосходит по этим показателям РФ в 5 раз. Для многих непредвзятых экономических аналитиков, социологов стало ясно, что в нынешней геополитической ситуации «у нас нет иного выбора, кроме смены социально-экономической модели, поскольку правление рыночных неолибералов наглядно показало, что ничего кроме уродливого, примитивного, феодально-олигархического капитализма, находящегося в критической неоколониальной зависимости от западных технологий, продовольствия, капитала и нефтедолларов, они построить не в состоянии»[1]. Основные пути сокращения социального неравенства хорошо известны и просчитаны экспертами для российских условий. Социально-рыночная экономика это: введение прогрессивной шкалы налогообложения (применяемой в развитых странах мира); налога на богатство и роскошь; мероприятия по формированию эффективного рынка труда; снижение неравенства доходов за счет социальных трансферов и повышения минимальных гарантий в сфере социального обеспечения. Только введение прогрессивной шкалы на совокупные доходы, по подсчётам специалистов института социальноэкономических проблем народонаселения РАН, позволит увеличить пенсии в 4 раза, минимальную зарплату в 3,5 раза, зарплату бюджетникам - в 2,5 раза. Реализация этих и других мероприятий - вопрос политической воли власть предержащих[1].

Многие известные отечественные экономисты (в первую очередь С. Глазьев, М. Делягин) считают необходимым введение в рыночную экономику планового сегмента, усиление роли государства в управлении социально-экономическими процессами. По мнению доктора технических наук Г.В. Костина, двухуровневый (плановый и рыночный) механизм развития общества и производительных сил при разном соотношении их может обеспечить от 6\% до 15\% годового экономического роста (чем выше плановый сектор, тем выше экономический рост) [6].

В условиях рыночного хозяйства человек может обеспечить удовлетворение своих потребностей лишь путём получения доходов от собственности или в виде заработной платы за свой труд. Но в каждом обществе, отмечают Л. Дмитриева и В. Ахмеева, есть определённая часть населения, которая не имеет возможности и не в состоянии трудиться в силу болезни, нетрудоспособности, старости или возраста, не позволяющих человеку вступить в сферу производственных отношений, равно как и людей, пострадавших вследствие экономических, экологических, национальных, политических и военных конфликтов, стихийных бедствий: «Эти категории населения не выживут без защиты и социальной помощи государства, когда главным фактором производства и распределения является капитал» [3]. 
Эффективная социальная политика, по мнению авторов, является фактором экономического роста, поскольку:

- повышает возможности населения уплачивать налоги, что, в свою очередь, увеличивает доходную часть государственного бюджета;

- увеличивает доходы и сбережения населения, которые служат новыми источниками для инвестиций;

- сокращает количество индивидов, нуждающихся в социальной помощи, что ослабляет нагрузку на расходную часть госбюджета, повышает его сбалансированность;

- повышает спрос на товары и услуги, что стимулирует экономический рост;

- повышает образовательный и квалификационный уровень рабочей силы, главного фактора экономического роста.

Пока что система социальной защиты находится в стадии формирования[2].

Социальным может считаться лишь то государство, которое способно не только декларировать высокие идеалы, но и готово проводить сильную и ответственную социальную политику на основе соответствующих установок и национальных возможностей, на основе принципов демократизма, законности и гуманизма. Проводимая российским правительством социальная политика, по мнению члена-корреспондента РАН, директора Института социально-экономических проблем народонаселения Н.М. Римашевской, не отличается достаточной чёткостью, перспективной направленностью и прочностью правовой базы; в ней много декларативного, конъюнктурнопопулистского, стратегически слабо продуманного [5].

За последнее десятилетие, особенно с 2013 года, социальноэкономическая ситуация в стране ещё более осложнилась. Растут бедность, безработица, закрываются предприятия, идёт банкротство субъектов частного бизнеса, увеличение тарифов и стоимости услуг ЖКХ, безудержный рост цен на товары повседневного спроса. Усиливается коррупция (только за 2016 год выявлено более 300 тысяч преступлений коррупционной направленности), злоупотребления, халатно-бюрократическое отношение к нуждам и бедам людей, колоссальная дифференциация в доходах властных структур и трудового населения, скрываемая в так называемой «средней зарплате». Вот её оценка известными публицистами: «В своём нынешнем виде вся экономическая политика власти независимо от деклараций, де-факто осуществляется в интересах богатого меньшинства и вопреки интересам и представлениям о справедливости подавляющего большинства населения» [2]. И формирование социального государства, по мнению профессора Е.В. Охотского, в нашей стране находится на самом начальном уровне[13].

Эксперты, независимо от их принадлежности к различным школам и партийно-политическим направлениям, единодушно сходятся в том, что для современной социальной политики характерно отсутствие целостной стратегии[13]. 
В результате «реформ» в постсоветской России «построен симулякр западного общества - с формальными признаками демократии, но презирающий её суть, с западными потребностями, но без западных источников дохода, а главное - с культом наживы, но без протестантской этики, ограничивающей её разрушительную силу», который привёл к взрывному развитию антисоциальной и антигуманной философии и морали, консолидации её носителей и выразителей, внедрению в сознание молодёжи идей социалдарвинизма, жестокости, алчности, колоссальному росту неравенства[2]. По данным Росстата коэффициент дифференциации в среднем по России приблизился к 17, в Москве доходит до 43. Но данные Росстата крайне лукавы, отмечают специалисты, в том числе В. Симчера, бывший его руководитель. Они учитывают лишь часть денежных доходов - «белую» зарплату, составляющую львиную долю (а в большинстве своём полную) доходов малоимущих россиян и малую часть наиболее богатых слоёв общества. За пределами оценок Росстата остаются доходы от предпринимательской деятельности, дивиденды, доходы от продажи имущества и ценных бумаг, генерируемые и оседающие в оффшорных юрисдикциях прибыли, скрытые доходы от неформальной занятости[12]. Анализируя отчёт Роскомстата за январь-сентябрь 2016 года, В. Симчера отмечал, что официальная статистика инфляции в 5,5\% не учитывает социальную инфляцию и инфляцию издержек. Поэтому инфляция в 2016 году определённо превысит уровень 2015 года, когда она составила $13 \%$. По расчётам независимых экспертов разрыв в уровне доходов $10 \%$ высших и низших слоев населения находится в пропорции 40:1 и продолжает расти, увеличиваясь ныне, по расчётам С.Батчикова и В.Жуковского, до 100 раз[2].

По расчётам международного агентства «Statistics Group», базирующихся, кстати, на материалах Росстата, хотя и с поправкой на западноевропейские определения нищеты и бедности, в России в 2011 году 90,9\% населения с переменным успехом балансировало у черты бедности: крайне нищие $-13,4 \%$, нищие - $28,7 \%$, бедные - 38,8\%, повыше бедности - $10,2 \%$, среднего достатка $-7,3 \%$, состоятельные $-1,1 \%$, богатые $-0,7 \%$. По расчётам отечественных экономистов, одному проценту богатеев принадлежит $71 \%$ всех личных активов россиян. По мнению А. Кобякова, - это Африка, общество, где одни социальные группы ненавидят другие, в котором гарантированно создаётся почва для радикальных потрясений. И эта инерционная тенденция к углублению социального разрыва, по его оценке, входит в противоречие с озвученными В.В.Путиным целевыми ориентирами социальной политики, с целями консолидации общества и поступательным движением экономики. А потому необходимо формирование действительно социальной рыночной системы, ускорение экономического роста, придания общественным отношениям большей гармонизации[4]. Автор не требует смены либерально-рыночного капиталистического курса, а лишь усиления социальной составляющей, приведения социального неравенства к разумным пропорциям. 
Своё воздействие на справедливое решение социально-экономических проблем страны оказывает Русская православная церковь. Начиная с юбилейного Архиерейского собора в августе 2000 года в Москве, принявшего «Основы социальной концепции», а затем VII Всемирного русского народного собора в декабре 2002 года, проигнорированного, кстати, власть предержащими, закрепившего основополагающие православные ценности: общее благо, благотворительность, решение социальных проблем, сохранение и развитие культурного наследия, общественная нравственность. Тогда же возникло понятие «православного социализма», вызвавшего позитивную реакцию в общественно-политических кругах, прежде всего патриотической и левой ориентации и их структурах, в частности Изборского клуба. Идеи и ценности «православного социализма» нашли своё отражение в программатике ряда мыслителей и политических деятелей. В представленном президентскому Совету по безопасности С. Глазьевым докладе «О необходимых мерах по укреплению экономической безопасности России» совмещены ценности социального прогресса, социальной справедливости и творческой свободы человека в рамках модели «православного социализма», базирующегося на идеях коммунизма и христианства [7].

Надежды на «революцию сверху», на которую рассчитывали патриотические силы в 2014-2016 годах, не оправдались. И если в сфере внешней политики и оборонного строительства В.В. Путин осуществил резкий разворот в защиту национальных интересов России, то «этого разворота не просто нет, но даже усиливаются либеральные тенденции, прежде всего в финансовоэкономической сфере» [11]. И правительство Д. Медведева, отодвинувшее на задний план социальную политику и её основной принцип - социальную справедливость - фактически не реализует стратегические цели Концепции долгосрочного социально-экономического развития РФ до 2020 года.

В преддверии 100-летия Великой Октябрьской социалистической революции и реализации в СССР принципа социального равенства правящие круги должны, наконец, осознать глубину народного недовольства, отказаться от вульгарного неолиберализма и догм «вашингтонского консенсуса» и пока не грянул гром, начать реализацию подлинно справедливой и необходимой трудящимся социально-экономической политики. Но таковая может начаться только при активной борьбе трудящихся, находящихся ныне в дезорганизованности, раздробленности, в своего рода «летаргическом сне».

\section{Источники и литература:}

1. Охотский Е.В., Богучарская В.А. Современное государство и социальная политика современной России: ориентация на результат//Труд и социальные отношения, 2012, №5(95). C.30-44.

2. Путин В. Строительство справедливости. Социальная политика для России//Комсомольская правда, 2012, 13 февраля.

3. Отчёт правительства о результатов работы в 2014 году 21 апреля 2015 года в Государственной Думе ФС РФ// www.government.ru.

4. Батчиков С., Жуковский В. Беда - разруха в головах. О чём умолчал Медведев в Госдуме// Завтра, 2015, №19(1120). 
5. Костин Г.В. Принципы и механизмы выбора эффективной социальноэкономической модели развития//Слова и дела, 2015, №38-39(61).

6. Дмитриева Л.А., Ахмеева В.И. Особенности социальной политики в современной России//http:www.rae.ru.

7. Батчиков С., Жуковский В. Битва с неравенством// Завтра, 2015, №25(1126).

8. Концепция социального государства Российской Федерации. Материалы научнопрактической конференции «Социальное государство: опыт и проблемы», 20 января 2004 г.//Под общей редакцией Грищенко Н.Н., М., 2004. 241 с.

9. Чирикова А.Е. Социальная политика в современной России: субъекты и региональная практика//URZ:/www.civilblock.ru.

10. Симчера В. У нас всё в порядке! А так ли это?//Завтра, 2017, №5(1209).

11. Кобяков А. Социальная пропасть. Уровень неравенства в России: угроза безопасности и тормоз развития//Завтра, 2013, 34 (1031).

12. Нагорный А., Коньков Н. Глазьев и план «революции сверху»//Завтра, 2015, №38 (1139).

13. Революция сверху! Выучила ли Россия уроки столетней давности//Завтра, 2017, №2 (1206).

\section{Referenses}

1. Ohotskij E.V., Bogucharskaya V.A. Sovremennoe gosudarstvo i social'naya politika sovremennoj Rossii: orientaciya na rezul'tat//Trud i social'nye otnosheniya, 2012, №5(95). S.30-44.

2. Putin V. Stroitel'stvo spravedlivosti. Social'naya politika dlya Rossii//Komsomol'skaya pravda, 2012, 13 fevralya.

3. Otchyot pravitel'stva o rezul'tatov raboty v 2014 godu 21 aprelya 2015 goda v Gosudarstvennoj Dume FS RF// www.government.ru.

4. Batchikov S., ZHukovskij V. Beda - razruha v golovah. O chem umolchal Medvedev v Gosdume// Zavtra, 2015, №19(1120).

5. Kostin G.V. Principy i mekhanizmy vybora ehffektivnoj social'no-ehkonomicheskoj modeli razvitiya//Slova i dela, 2015, №38-39(61).

6. Dmitrieva L.A., Ahmeeva V.I. Osobennosti social'noj politiki v sovremennoj Rossii//http:www.rae.ru

7. Batchikov S., ZHukovskij V. Bitva s neravenstvom// Zavtra, 2015, №25(1126).

8. Koncepciya social'nogo gosudarstva Rossijskoj Federacii. Materialy nauchnoprakticheskoj konferencii «Social'noe gosudarstvo: opyt i problemy», 20 yanvarya 2004 g.//Pod obshchej redakciej Grishchenko N.N., M., 2004. 241 s.

9. CHirikova A.E. Social'naya politika v sovremennoj Rossii: sub"ekty i regional'naya praktika//URZ:/www.civilblock.ru

10. Simchera V. U nas vsyo v poryadke! A tak li ehto?//Zavtra, 2017, №5(1209).

11. Kobyakov A. Social'naya propast'. Uroven' neravenstva v Rossii: ugroza bezopasnosti i tormoz razvitiya//Zavtra, 2013, 34 (1031).

12. Nagornyj A., Kon'kov N. Glaz'ev i plan «revolyucii sverhu»//Zavtra, 2015, №38(1139)

13. Revolyuciya sverhu! Vyuchila li Rossiya uroki stoletnej davnosti//Zavtra, 2017, №2 (1206). 